Check for updates

The BMJ

Cite this as: BMJ 2020;370:m3327 http://dx.doi.org/10.1136/bmj.m3327 Published: 25 August 2020

\section{Covid-19: US approves emergency use of convalescent plasma despite warnings over lack of evidence}

\author{
Elisabeth Mahase
}

The US Food and Drug Administration has approved convalescent plasma for emergency use in hospital patients with covid-19. ${ }^{1}$

The announcement on 23 August said that the FDA had concluded that plasma from recovered patients "may be effective" in treating the virus and that the "potential benefits of the product outweigh the known and potential risks." The move came despite the absence of results from randomised controlled trials, with only a preprint paper on the effects on hospitalised covid-19 patients being published to date.

The preprint, published on medRxiv on 12 August, examined whether plasma reduced mortality, and included 35000 patients who received transfusions between 4 April and 4 July at one of the 2800 participating US centres. ${ }^{2}$ The study, not yet peer reviewed, said, "Earlier use of convalescent plasma was associated with lower observed rates of 7 -day and 30-day mortality. The use of convalescent plasma with higher antibody levels was associated with reduced 7-day and 30-day mortality."

Experts have warned that although these early findings show promise there is not enough evidence to show that it works.

Plasma from recovered patients was approved on a case by case basis by the FDA for people critically ill with covid-19 in March. ${ }^{3}$ Since then more than 70 ooo patients have been treated with plasma. Emergency use approval allows clinicians to use unapproved medical products to diagnose, treat, or prevent serious or life threatening diseases or conditions when there are no adequate, approved, and available alternatives.

In its announcement the FDA said, "The FDA determined that it is reasonable to believe that covid-19 convalescent plasma may be effective in lessening the severity or shortening the length of covid-19 illness in some hospitalized patients ... The FDA continues to recommend that the designs of ongoing randomized clinical trials of covid-19 convalescent plasma and other therapeutic agents remain unaltered, as covid-19 convalescent plasma does not yet represent a new standard of care based on the current available evidence."

The FDA's commissioner, Stephen Hahn, said, "I am committed to releasing safe and potentially helpful treatments for covid-19 as quickly as possible in order to save lives. We're encouraged by the early promising data that we've seen about convalescent plasma. The data from studies conducted this year shows that plasma from patients who've recovered from covid-19 has the potential to help treat those who are suffering from the effects of getting this terrible virus."

But Martin Landray, professor of medicine and epidemiology at the University of Oxford and lead researcher for the RECOVERY trial, which is comparing treatments for covid-19, including convalescent plasma for hospital patients, urged caution. He said, "There is a huge gap between theory and proven benefit. That is why randomised clinical trials are so important. At present, we simply don't know if it works.

"It is unfortunate that despite the scale of the epidemic in the US and their rich history of rigorous clinical research, so many patients continue to be given an unproven treatment. If just a few thousand patients were to be randomised, we would have the answer. If effective, convalescent plasma could be rapidly used worldwide. If not, it could be abandoned.

"Here in the UK we have taken a different approach: the RECOVERY trial includes an assessment of convalescent plasma for patients hospitalised with covid-19 and will provide the evidence needed to treat patients appropriately. There can be no shortcuts-a pandemic is no time for guesswork. We need reliable evidence to deliver the best patient care.”

A spokesperson for NHS Blood and Transplant said, "The observational studies coming from America are promising and support the need for people to continue to donate convalescent plasma in England. However, they are not conclusive."

Hinton DM. Letter to Robert P Kadlec. FDA. 23 Aug 2020. https:/www.fda.gov/media/141477/download.

Joyner MJ, Senefeld JW, Klassen SA, et al. Effect of convalescent plasma on mortality among hospitalized patients with covid-19: initial three-month experience. MedRxiv. https://www.medrxiv.org/content/10.1101/2020.08.12.20169359v1.full.pdf.

3 Tanne JH. Covid-19: FDA approves use of convalescent plasma to treat critically ill patients. BMJ2020;368:m1256. doi: 10.1136/bmj.m1256 pmid: 32217555

This article is made freely available for use in accordance with BMJ's website terms and conditions for the duration of the covid-19 pandemic or until otherwise determined by BMJ. You may use, download and print the article for any lawful, non-commercial purpose (including text and data mining) provided that all copyright notices and trade marks are retained. 